\title{
Earnings management: Local or global phenomenon in the Visegrad Four?
}

\author{
Pavol Durana ${ }^{1, *}$, and Radovan Bacik ${ }^{2}$ \\ ${ }^{1}$ University of Zilina, Faculty of Operation and Economics of Transport and Communications, \\ Department of Economics, Univerzitna 1, 01026 Zilina, Slovakia \\ ${ }^{2}$ University of Presov, Faculty of Management, Department of Economics, Konstantinova 16, 08001 \\ Presov, Slovakia
}

\begin{abstract}
.
Research background: Increasing number of national scientific studies related to business finance shows that the earnings management phenomenon as a legal apparatus of manipulation business profit plays a significant role in financial reports in conditions of Slovak economy. Slovakia belongs to Visegrad Four, group of very historically and developmentally close countries. That is why it is relevant to compare the issue of earnings manipulation it these countries' context.

Purpose of the article: The main purpose of the article is to confirm global approach to manipulation of earnings in the Visegrad Four's enterprises and justify that managers incline to earnings management systematically in all analysed group not only at a local level in chosen country.

Methods: This econometric investigation used the observations of earnings before interest, taxes, depreciation and amortization of 1,058 Slovak enterprises, 688 Czech enterprises, 1,376 Polish enterprises and 731 Hungarian enterprises. It was investigated nine-years period from 2010 to 2018. Non-parametric time series trend modelling was run by MannKendall test and estimation of the slope of the trend by Sen's method used a linear model.

Findings \& Value added: The article focused on nine-years development of earnings before interest, taxes, depreciation and amortization in the Visegrad Four's enterprises. It was found out the systematic trend manipulation in all analysed countries. This fact highlighted that earnings management is not local phenomenon, but its development is globally preferred tool of business finance.
\end{abstract}

Keywords: business finance; earnings management; globalization; trend test and slope; time series

JEL Classification: $M 48$; $G 30 ; F 60$

\footnotetext{
* Corresponding author: pavol.durana@,fpedas.uniza.sk
} 


\section{Introduction}

The globalization is a process of interaction and integration among enterprises, a process driven by international trade and investment and aided by information technology. This process has effects on the environment, culture, political systems, economic development and prosperity around the world [1]. Each enterprise must adapt its activities to the current global situation and conditions [2]. Earnings management is a phenomenon of the legal apparatus of manipulation for the enterprises to be more successful in the global competition, but high-level earnings management can generate uncertainties in the short and long terms. The financial statements contain important financial information for the calculation of current and future cash flows [3]. In this case, it is critical to have welltrained staff with the practical experience and the knowledge of what to do [4]. Then, there are synergies caused by this concept of the risk management. However, this synergy must be supported by appropriate competencies of the managers [5]. That is way their approach should be systematic not random.

Thus, the main aim of the research is to confirm global approach to manipulation of earnings in the Visegrad Four's enterprises and justify that managers incline to the earnings management systematically in all analysed counties not only at a local level in chosen country. The time series analysis is used to fulfil the target. Time series analysis has a long tradition in economics and many new methods and approaches have emerged in the field of economic time series analysis in the recent years [6].

The article is structured as follows. In the introduction, the reason of the research and the importance of the issue of earnings management are delivered. Secondly, brief literature review is depicted, focusing on the recent topics of the analysed issue. Then, the next chapter portrays the structure of the data used and the adequacy of the apparatus of mathematical statistics (nonparametric Mann-Kendall and nonparametric Sen's slope) used to fulfil the set objective. The findings of the research are described in the results chapter. The part of the discussion compares the conclusions of previous Slovak studies to gained results of this study and sets the limitations and weakness. Finally, the possible ways of future research are noted.

\section{Literature Review}

This section contains recent studies in the field. [7] explains from basic econometrics how discretionary accruals are estimated, and in doing so why they are inappropriate measures for earnings management. It is shown that decisions of peer enterprise influence the regression coefficients, and hence residuals, in accruals models, which may lead to false conclusions about earnings management in other enterprises. [8] investigates the relationship between the aggregate of accounting earnings and the future Gross Domestic Product differentiating between developed and developing countries. This study uses data on Asian, African, and Pacific countries. [9] hypothesize that audits help to detect and correct overstatements. They test this fact using a difference-in-differences design, which compares audit adjustments to earnings for stock financed and cash-financed acquirers before versus after the acquisitions. [10] examine the consequences of real earnings management from an innovation perspective and investigate the patent output of enterprises likely to be managing earnings through altering their R\&D expenditures. [11] performs the analyses of earnings management and makes the estimates regarding most and used accounting software features, accounting software impact on financial errors, and cloud accounting software. The structural equation modelling technique is used to test the research model. [12] add technology-related behaviours and attitudes. [13] investigate the effect of environmental cost disclosure and social cost disclosure on financial performance 
mediated by earning management. To achieve this purpose, a quantitative research method is run by smart Partial Least Squares. [14] analyse the possibility of applying chosen fraudulent detection technique and assess its explanatory power. [15] examine the impact of institutional ownership and product market competition on earnings management (both accrual-based and real). [16] evaluate the earnings performance in tourism from the synergies of the state authorities, local authorities, and tourism business. [17] examine the effect of leverage on the form and extent of earnings management. Four models are employed to estimate the level of discretional accruals and real earnings management. [18] assess the impact of base erosion and profit shifting on multinational corporations' subsidiaries' performance in the Baltic countries. [19] examine the impact of multiple block holders on earnings management when the main conflict of interest is between controlling shareholder and other shareholders.

\section{Materials and methods}

This research builds on the research of [20]. Therefore, the same data is used. The secondary sources are observations of earnings before interest, taxes, depreciation and amortization (EBITDA) of Visegrad Four's enterprises. Visegrad economies are operating as small open economies affecting each other [21]. 1,347 Slovak enterprises, 859 Czech enterprises, 2,554 Polish enterprises and 880 Hungarian enterprises were originally extracted from the Amadeus database (provided by Moody' s analytics company Bureau van Dijk) capturing years 2010 to 2018 . The variable EBITDA is chosen to eliminate different tax, interest and depreciation policies of these emerging countries. The enterprises have to meet three set criteria: the value of total assets at the minimal level of 3,000,000 $€$; the value of total sales at the minimal level of 2,000,000 $€$; the value of net income at least $100,000 €[20]$. The Grubbs test was used to detect the occurrence of inconsistent data in the samples. The final samples after removal of the outliers are as follows. 1,058 Slovak enterprises (289 outliers), 688 Czech enterprises (171 outliers), 1,376 Polish enterprises (1,178 outliers), and 731 Hungarian enterprises (149 outliers) [20]. Then, the central value of financial data was calculated for every year and for every country. The Figure 1 shows the development of annual EBITDA in Visegrad Four during nine-year period. The Table 1 contains the summary statistics of analysed time series for all countries.

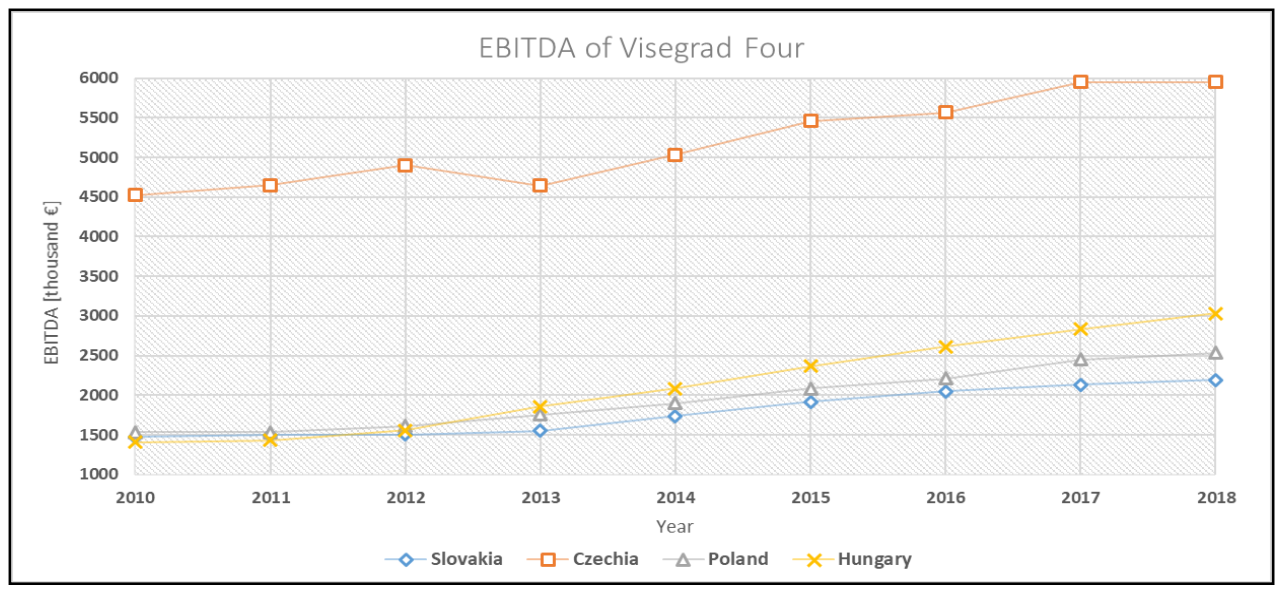

Fig. 1. Development of EBITDA in Visegrad Four.

Source: own research. 
Table 1. Summary statistics. Source: own research.

\begin{tabular}{|c|c|c|c|c|}
\hline Country & Minimum & Maximum & Mean & Standard deviation \\
\hline Slovakia & 1471.379 & 2191.428 & 1783.783 & 293.079 \\
\hline Czechia & 4526.141 & 5952.932 & 5187.009 & 559.858 \\
\hline Poland & 1531.875 & 2533.370 & 1956.466 & 383.930 \\
\hline Hungary & 1410.031 & 3033.357 & 2131.847 & 614.509 \\
\hline
\end{tabular}

Following methodological steps were used:

1. The confirmation of the systematic trend.

The distribution of the data and the serial correlation of the data are not tested in this research. That is way the nonparametric alternative of trend test is run. Mann-Kendall trend is chosen to detect systematic trends of the earnings manipulation. This test can be used if there are no ties in the time series and if the sample size is less than 50 observations. The null hypothesis indicates the randomness, it means no systematic trend in the manipulation of EBITDA in the Visegrad Four. The alternative hypothesis supports the occurrence of the trend. If one can reject the null hypothesis for all four countries, it can be confirmed the statement that managers incline to do the earnings management globally in all countries of the Visegrad Four not only in the individual country.

The analysis allows us to formulate the following hypothesis which is tested at the significance level alpha 0.05 :

$H_{0}$ : There is no systematic trend in the manipulation of EBITDA in the Visegrad Four.

$H_{1}$ : There is a systematic trend in the manipulation of EBITDA in the Visegrad Four.

2. The estimation of the slope of the trend.

The slope of the trend and the intercept are recommended to estimate by more robust nonparametric Sen's method using a linear model. Sen's slope and intercept of liner regression model are computed for all countries of the Visegrad Group with the application of the continuity correction.

\section{Results}

Firstly, Mann-Kendall trend is run to identify the trend or randomness in the manipulation of EBITDA in the Visegrad Four.

$H_{0}$ : There is no systematic trend in the manipulation of EBITDA in the Visegrad Four.

$H_{1}$ : There is a systematic trend in the manipulation of EBITDA in the Visegrad Four.

Table 2. Mann-Kendall trend test (Two-tailed test). Source: own research.

\begin{tabular}{|c|c|c|}
\hline Country & p-value & alpha \\
\hline Slovakia & 0.000 & 0.05 \\
\hline Czechia & 0.001 & 0.05 \\
\hline Poland & 0.001 & 0.05 \\
\hline Hungary & 0.000 & 0.05 \\
\hline
\end{tabular}

As the computed p-value is lower than the significance level alpha, one can reject the null hypothesis, and accept the alternative hypothesis based on the Table 2 . The systematic manipulation is proved for all countries of the Visegrad Group. The phenomenon of the earnings management is used globally not locally in the Visegrad Four. 
Table 3. Sen's slope. Source: own research.

\begin{tabular}{|c|c|c|}
\hline Country & Slope & Intercept \\
\hline Slovakia & 105.03025 & -209718.66575 \\
\hline Czechia & 187.9666 & -373351.4666 \\
\hline Poland & 146.098 & -292304.384 \\
\hline Hungary & 234.0503 & $-469245,62067$ \\
\hline
\end{tabular}

Secondly, the Sen's slope of liner regression model is calculated for all countries of the Visegrad Four (Table 3). The biggest value of the slope is determined for Hungarian model of EBITDA and the lowest one for Slovakia. Table 3 also depicts the intercepts of models. Figure 2, Figure 3, Figure 4, Figure 5 show sequentially the individual model for every country.

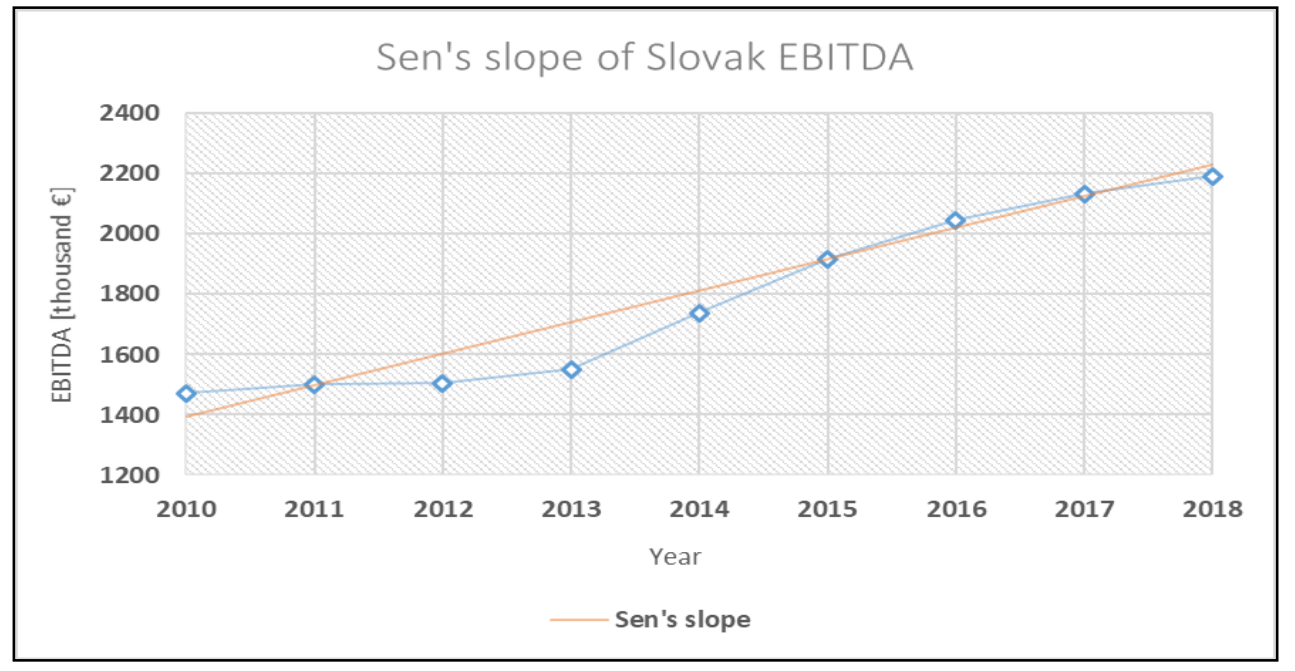

Fig. 2. Sen's slope of Slovak EBITDA.

Source: own research.

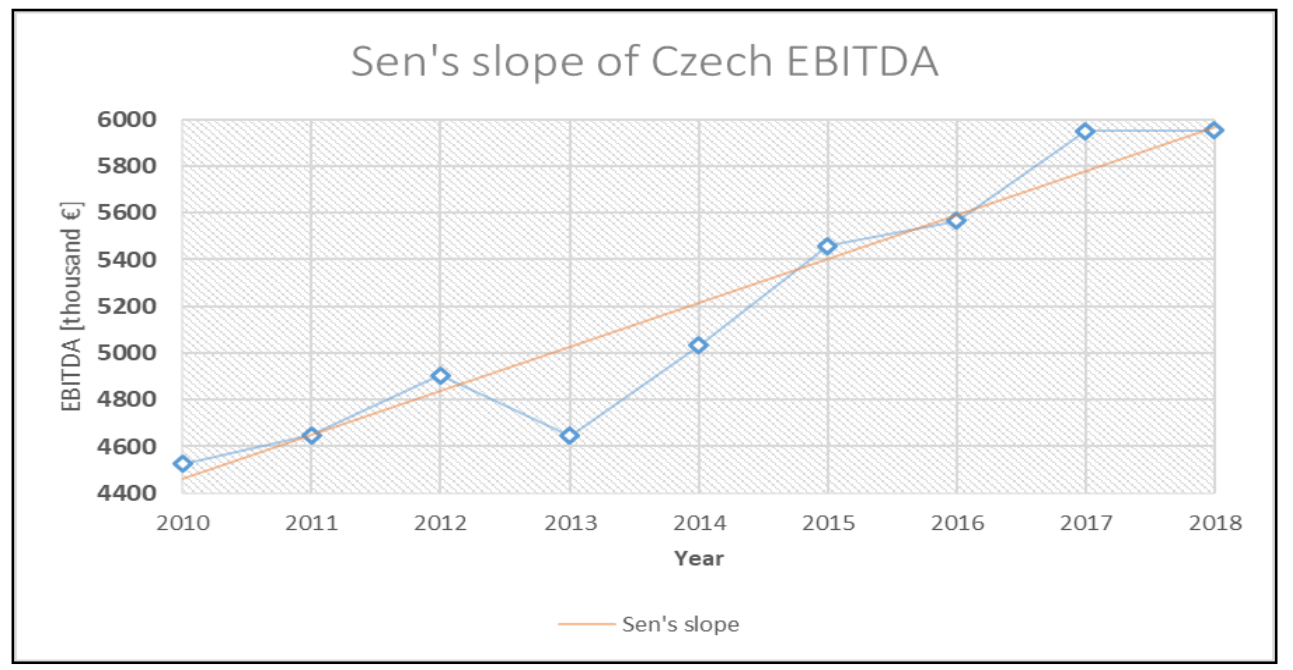

Fig. 3. Sen's slope of Czech EBITDA.

Source: own research. 


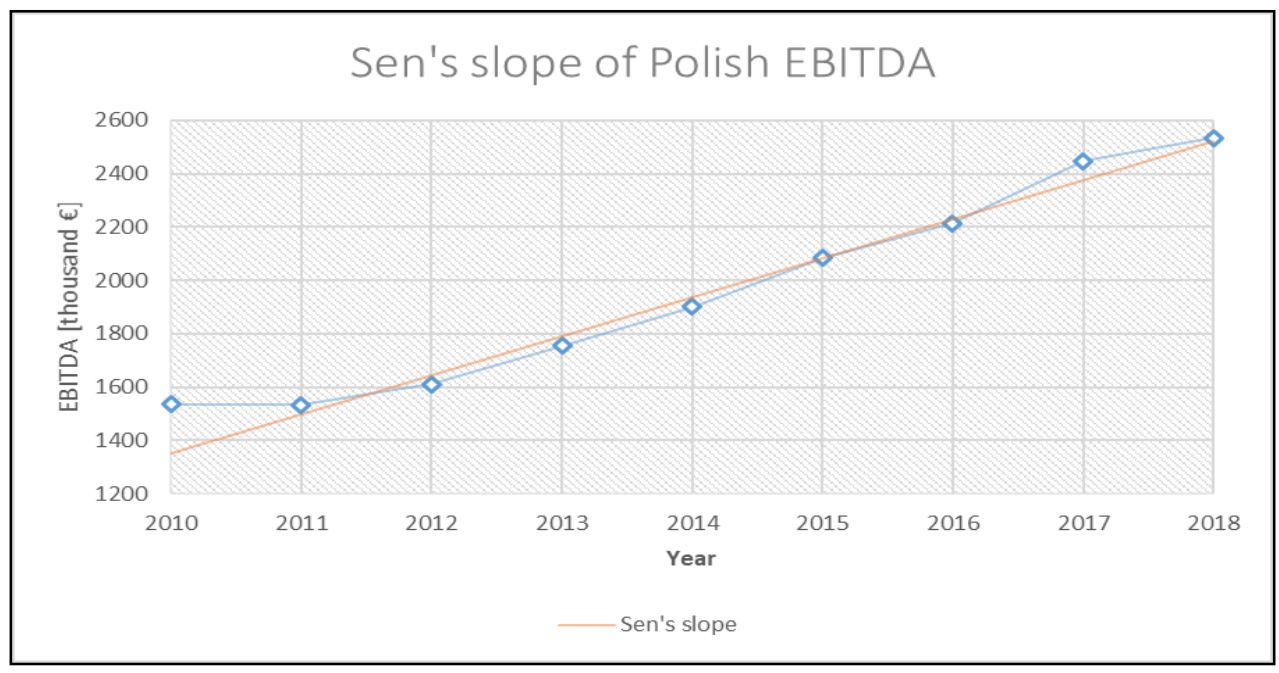

Fig. 4. Sen's slope of Polish EBITDA.

Source: own research.

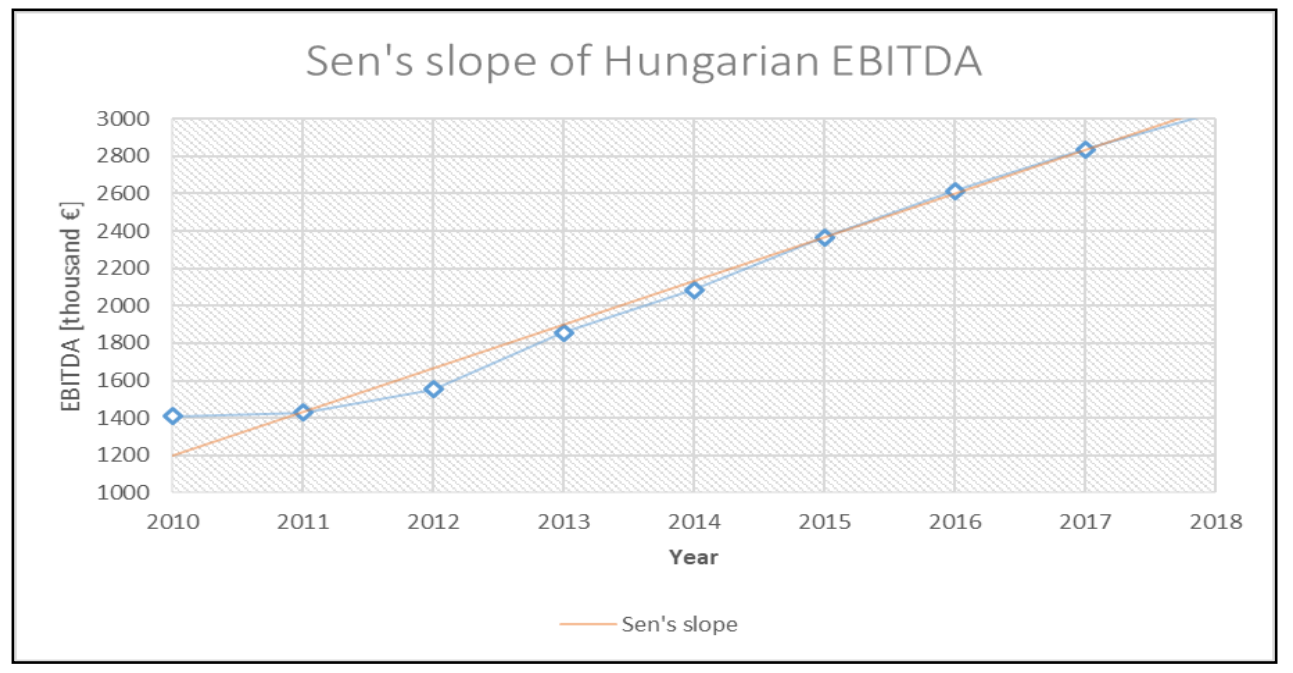

Fig. 5. Sen's slope of Hungarian EBITDA.

Source: own research.

\section{Discussion}

The findings of the study are compared to the recent Slovak researches from the analysed field in this chapter. The investigation of this paper focuses on the earnings management generally, for all sectors. [22] evaluate the financial performance of the enterprises in IT sector under the conditions of globalized world. [23] analyse agriculture, forestry, and fishing sector in Slovakia which is highly affected by earnings manipulation. They use receiver operating characteristic curves and the outputs confirm that a large proportion of the enterprises in this sector tend to use earnings management or creative accounting. The results of [24] duplicate the conclusions of this research, that earnings management is not local but global phenomenon. Their study tests the dependence between the earnings management and the region, where the enterprise does business. It is indicated that there is 
not a statically significant relation between these variables, earnings managing is done globally not only in individual regions. [25] use the statistical sample of Slovak and Czech enterprises to reveal manipulation with earnings by the Kothari model and the Friedman non-parametric test. The study identifies the fact that the analysed countries tend to manipulate earnings upwards. [26] reject the randomness in the managing of the earnings as well. Their research focuses on significant years of the manipulation. The year 2014 is detected as a breakpoint for Slovak, Polish and Hungarian enterprises considering the earnings manipulation. The year 2013 is marked as a change-point in Czech enterprises based on Buishand test.

The first limitation of the research is caused by the analysing only the nine-year period of earnings before interest, taxes, depreciation and amortization in the Visegrad Four's enterprises. Another limitation might be the running and the preference of the nonparametric trend test to the parametric one. Finally, the study is limited by the using of unequal number of the enterprises in the final samples of individual countries.

The following areas are potential directions of the future research: extending the research for Baltics (Estonia, Latvia, and Lithuania), decomposition of the research for each sector of the national economies, and comprehensive using of time series apparatus for the detection of global phenomenon labelled earnings management.

This paper was supported by the Slovak Research and Development Agency under Grant number APVV-17-0546: Variant Comprehensive Model of Earnings Management in Conditions of the Slovak Republic as an Essential Instrument of Market Uncertainty Reduction.

\section{References}

1. Hadas-Dyduch, M. (2019). China - Globalization world empirical analysis of connections. Ekonomicko-manazerske spektrum, 13(2), 81-88.

2. Kampova, K., Makka, K., Zvarikova, K. (2020). Cost benefit analysis within organization security management. SHS Web of Conferences, 74, 01010.

3. Khuong, N. V., Liem, N. T., Minh, M. T. H. (2020). Earnings management and cash holdings: evidence from energy firms in Vietnam. Journal of International Studies, 13(1), 247-261.

4. Kampova, K., Makka, K., Zvakova, Z., Pellowski, W. (2018). The eSEC portal as a tool for the concept of corporate social responsibility. In F. Jakab (Ed), 16th International Conference on Emerging Elearning Technologies and Appplications (pp. 261-266). USA: IEEE.

5. Makka, K., Kampova, K., Boros, M. (2019). Workplace training in the fuels distribution company. In L. Goméz Chova, A. Lopez Martine \& I. Candel Torres (Eds), 13th International Technology, Education and Development Conference (INTED2019) (pp. 3990-3995). Valencia: IATED Academy.

6. Gaspareniene, L., Remeikiene, R. (2020). Arima model for predicting the development of the price of gold: European approach. Ekonomicko-manazerske spektrum, 14(1), 8796.

7. Jackson, A. B. (2018). Discretionary Accruals: Earnings Management...or Not? Abacus, 54(2), 136-153.

8. Sumiyana, S. (2020). Different characteristics of the aggregate of accounting earnings between developed and developing countries: evidence for predicting future GDP. Journal of International Studies, 13(1), 58-80. 
9. Lennox, C., Wang, Z. T., Wu, X. (2018). Earnings management, audit adjustments, and the financing of corporate acquisitions: Evidence from China. Journal of Accounting and Economics, 65(1), 21-40.

10. Bereskin, F. L., Hsu, P. H., Rotenberg, W. (2018). The real effects of real earnings management. Contemporary Accounting Research, 35(1), 525-557.

11. Ionescu, L. (2019). Big data, blockchain, and artificial intelligence in cloud-based accounting information systems. Analysis and Metaphysics, 18, 44-49.

12. Taylor, P., Kral, P., Vrbka, J., Gregova, E. (2020). Problematic smartphone use, social anxiety symptom severity, and technology-related behaviors and attitudes. Analysis and Metaphysics, 19, 73-79.

13. Ayu, M., Gamayuni, R. R., Urbanski, M. (2020). The impact of environmental and social costs disclosure on financial performance mediating by earning management. Polish Journal of Management Studies, 21(1), 74-86.

14. Kramarova, K., Valaskova, K. (2020). Application of chosen fraudulent detection technique in the Slovak business environment. SHS Web of Conference, 74, 01019.

15. Lemma, T. T., Negash, M., Mlilo, M., Lulseged, A. (2018). Institutional ownership, product market competition, and earnings management: some evidence from international data. Journal of Business Research, 90, 151-163.

16. Angelova, G., Parvanov, P., Chetrafilov, G., Krasteva, N. Y., Krastev, V. I. (2017). Sustainability in tourism cadre training and selection in Bulgaria perceptions of university students on their skills. Revista Inclusiones, 4(3), 144-156.

17. Khanh, M.T.H, Thu, P. A. (2019). The effect of financial leverage on real and accrualbased earnings management in Vietnamese firms. Economics and Sociology, 12(4), 299-312.

18. Kundelis, E, Legenzova, R. (2019). Assessing impact of base erosion and profit shifting on performance of subsidiaries of multinational corporations in Baltic countries. Equilibrium - Quarterly Journal of Economics and Economic Policy, 14(2), 277-293.

19. Jiang, F., Ma, Y., Wang, X. (2020). Multiple blockholders and earnings management. Journal of Corporate Finance, 64, 101689.

20. Valaskova, K., Gavurova, B., Durana, P., Kovacova, M. (2020). Alter ego only four times? The case study of business profits in the Visegrad Group. E\&M Economics and Management, 23(3), 101-119.

21. Bartekova, M. Slahor, L. (2018). Economic peformance estimation of the Visegrad Group countries. In A. Maloletko, N. Rupcic, Z. Baracskai (Eds), 34th International Scientific Conference on Economic and Social Development (pp. 180-187). Croatia: Varazdin Development \& Entrepreneurship Agency.

22. Blazek, R., Durana, P., Valaskova, K. (2020). Creative accounting as an apparatus for reporting profits in agribusiness. Journal of Risk and Financial Management, 13(11), 261.

23. Siekelova, A., Kovacova, M., Adamko, P., Stehel, V. (2019). Profit management as an instrument for SMEs developing: the case for Slovakia. Marketing and Management of Innovations, 3, 285-296.

24. Podhorska, I., Siekelova, A. (2020). Enterprises financial performance in a globalized world. SHS Web of Conferences, 74, 05018. 
25. Kliestik, T., Nica, E., Suler, P.,Valaskova, K. (2020). Innovations in the company's earning management: the case for the Czech Republic and Slovakia. Marketing and Management of Innovations, 3, 332-345.

26. Kliestik, T., Valaskova, K., Nica, E., Kovacova, M., Lazaroiu, G. (2020). Advanced methods of earnings management: monotonic trends and change-points under spotlight in the Visegrad countries. Oeconomia Copernicana, 11(2), 371-400. 